\title{
PROPOSAL OF BROWNFIELD LAND DEVELOPMENT ON THE EXAMPLE OF THE LANDFILLS OF FORMER KRAKOW SODA WORKS „SOLVAY”
}

\author{
Maciej Gliniak', Wiktoria Sobczyk ${ }^{2}$ \\ 1 University of Agriculture in Krakow, Faculty of Production and Power Engineering, Institute of Agricultural \\ Engineering and Informatics, Department of Technical Infrastructure and Ecoenergetic, Krakow, Poland, \\ e-mail:m.gliniak@ur.krakow.pl \\ 2 AGH University of Science and Technology, Faculty of Mining and Geoengineering, Department of \\ Environmental Engineering and Mineral Processing, Krakow, Poland
}

Received: 2016.08.11

Accepted: 2016.09 .26

Published: 2016.11.01

\begin{abstract}
The article presents a proposal for the development of soda industry landfills on the example of a former Cracow Soda Works "Solvay". The area is located in close proximity to the center of Krakow and is surrounded by places of worship. The analyzed area is characterized by specific physical and chemical properties of the substrate (soda production waste) that manifest themselves e.g. in very high salinity and the presence of numerous processes of water erosion. The former landfill covers an area of $1 \mathrm{~km}^{2}$ and is a natural link between the two large settlements in the southern part of Krakow, namely Kurdwanów and Borek Fałęcki. The developed landscape concept is based on a detailed analysis of the physicochemical substrate and the conditions necessary for the foundation of buildings and civil engineering. In the research phase, the technical and natural inventory was made, and a detailed review of the literature in the field of land use with similar properties was performed. The designing process was guided by the information contained in the available planning documents and the needs of the local community, which presented in the literature of other scientists. As a result of the research, the concept of omni-zoning area landfills was established. The main assumptions are based on the concept of the nineteenth-century idea of the garden city, consisting in dividing the area into 6 main thematic areas, i.e. parks, which are described in detail in the article. The main functions (leisure and recreation) have been supplemented with historical and touristic elements.
\end{abstract}

Keywords: landfill landscape development, Krakow, soda industry

\section{INTRODUCTION}

Differentiation of the physicochemical properties of waste stored in landfills of former Cracow Soda Works was the subject of numerous scientific papers devoted to the possibilities of development of this area. The first local spatial development plan (Biuro Rozwoju Krakowa 1994) allocated this area for low greenery ,as designed by Nagawiecka et al. (1980) and Sanecki (1994). Ten years later, the concept of developing this area, maintains the assumptions of the foundation plan from 1994 and supplements that paper with recreational features (Instytut Rozwoju Miast w
Krakowie 2004). Assumptions of the project from 2004 were confirmed through biochemical studies by Pośpiech and Skalski (2006) and geotechnical analysis by Sroczyński (2008). Poda (1999), Krzak (2005) and Okrutniak (2010) also emphasize the validity of such concept.

At the end of 2012, the Krakow City Council passed a currently valid local development plan called "White Sea". The plan was partly abandoned from the maintenance of large green areas for the expansion of service areas and communication. Due to the partial development of the landfills area, (Uchwała... 2012) proposed a modified and supplemented land development conception 
from 2004. The project involves the maintenance of green areas of low safety landfill against water and aeolian erosion with development functions of recreation, sports and leisure. The sociological studies conducted by Ciechowski (2012) showed the need for such facilities.

Public acceptance of the planned works of revitalization is very important for the future and development of the brownfield area. The results of the surveys for different areas of degraded confirm recreational preferences and the natural development of these facilities by local residents (Sobczyk, Pawul 2010 a; Sobczyk, Pawul 2010 b).

\section{MULTIDIRECTIONAL LAND DEVELOPMENT CONCEPTION OF KZS "SOLVAY"}

The conception developed in 2003 by the Institute of Urban Development in Krakow constituted the basis for the preparation of the conception proposal Extending the plan of the whole complex of three tailing ponds with a total area of approximately $1 \mathrm{~km}^{2}$ (Fig. 1) is an innovative approach to spatial development of this area. The concept was made with regard to the current Polish law. The area of development includes:

- technical building difficulties on settlers crowns,

- significant salinity of the individual layers of deposited wastes,

- uneven and varied quality of the soil cover from technical reclamation.

Figure 1 shown the concept of dividing the territory of the former landfills KZS "Solvay" on 6 major sub-areas - Theme Parks. Subjects of the parks and their system have been integrated into the space that separates the two places of worship and provides their immediate surroundings. The project also envisages the creation of six viewing platforms at characteristic points of the various complexes sediment ponds.

\section{Contemplation Park}

The most important in the proposed conception is the Contemplation Park subarea, which combines area between the Sanctuary of Divine Mercy with the John Paul II Centre. It is located in the first and also the oldest landfill complex. The park has been divided into three main areas.
The largest of them is intended for the construction of the contemplative path, demarcated by the isolating greenery belts which help pilgrims focus on prayer. Other areas, directly adjacent to the John Paul II Center, have been appointed with the aim of pilgrims visiting the shrine. The zone immediately adjacent to the Centre will have the characteristics of monastic meditation garden intended for resting alone and contemplating the mysteries of the Christian faith. The last area, called the "Pontifical shepherd's hut", is intended for young visitors who want to learn about the religious history of the area. The following buildings of the shrine of John Paul II created a zone of catering, sanitary and Park\&Ride for people using the planned stop Fast Urban Railway and other Parks.

\section{Sport and Recreation Park and Culture Park}

The historical and social importance of former Soda Works "Solvay", had an impact on the decision concerning the landscape development proposal. The second landfills complex was dedicated to create a Sport and Recreation Park and Culture Park. The first one is located on the lower level of the complex and should be incorporate several multi-purpose sports fields, along with the necessary technical and sanitary facilities. The remaining area on the north side proposed to allocate for the construction of a multifunctional tennis courts. Land use designated for the Park of Culture should be preceded by a detailed study of the preferences of the local community. The central part of the Culture Park is occupied by low buildings housing service and sanitary facilities, adapted to the needs of future cultural objects. The spatial arrangement of Parks refers to the idea of the garden city of the early twentieth century, which was the original plan of the urban area of the Old Podgórze in Krakow. The main objective of the project is separating pedestrian and bicycle roads with greenery, which will create enclaves of individual character. The garden, which is located in the vicinity of the bridge over the river Wilga, should show the history of the Cracow Soda Works (with a sensory model for the blind), and the technology of soda production in one of the biggest post-war facilities of Europe. The second and third complex of settlers will be connected to the two footbridges for pedestrians and bicycle, located in the street wetlands, which will facilitate movement within the area covered by the plan and increase the safety of users. 


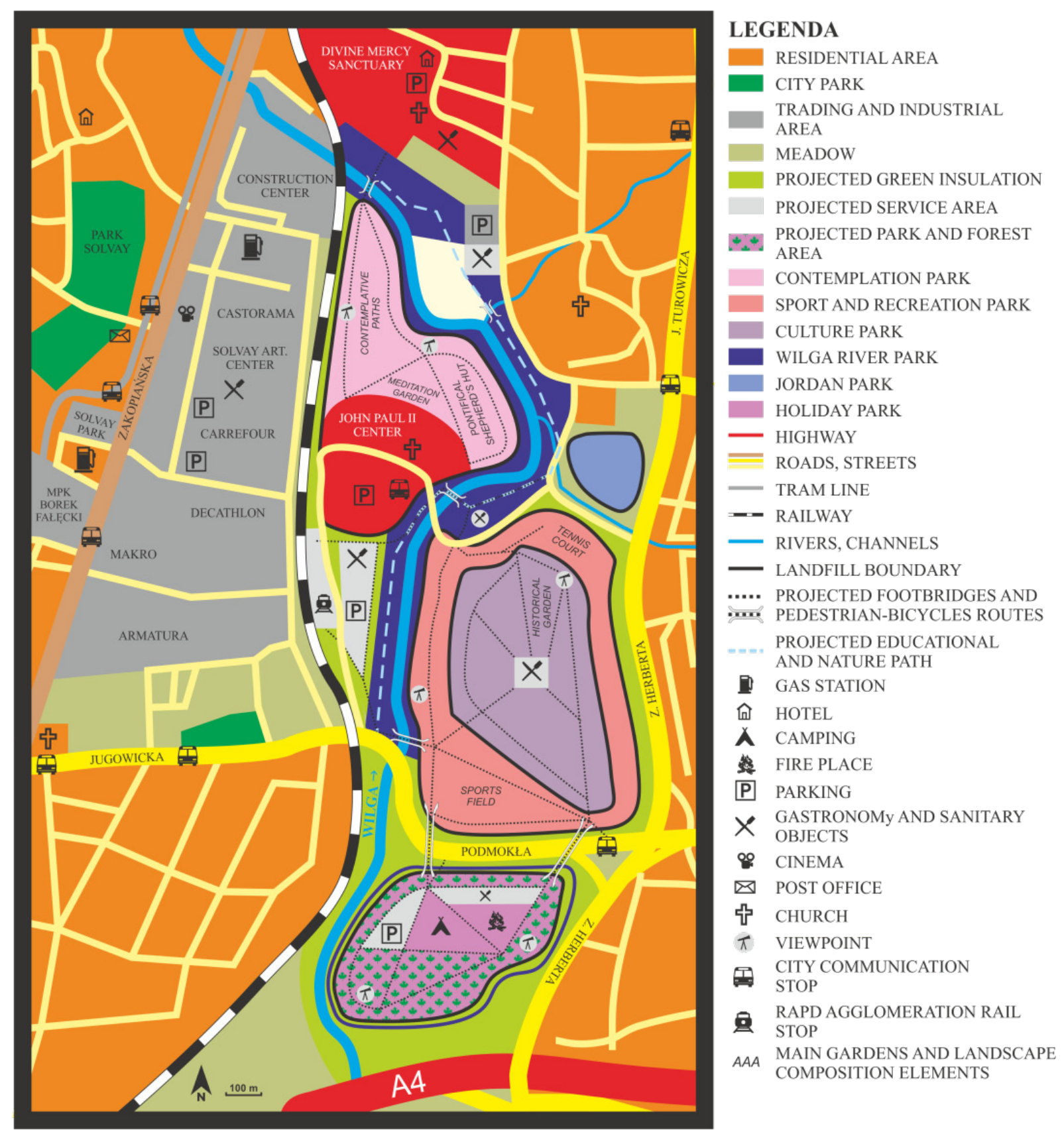

Figure 1. The concept of land development of former Krakow Soda Works „Solvay” landfills area.

\section{Holiday Park}

A Holiday Park was created in the third complex of former KZS "Solvay" landfills. In the northern part of the Park, there are marked areas for catering services, sanitation and tourism. In the central part of the complex, a campsite (with the possibility of adaptation to the campsite after the reconstruction of access roads) was created, designed for tourists visiting shrines and people who like to relax outdoors. Between the camping zones and services, a place surrounded by greenery, which is suitable for grilling, without disturbing the peace and quiet in the immediate vicinity. The remaining area of the Park has been earmarked for the development of forest parks, referring to its character camping in a natural environment away from the hustle and bustle of the city. In the southern part of the Park there are vantage points from which you can admire the panorama of Beskidy Mountains and distant mountain ranges of the Polish Carpathians.

\section{Wilga River Park}

The reclaimed area along the Wilga river forms River Park. Its main element is the educational and nature path. The main subject mat- 
ter and location of stops should take advantage of the educational value of this place. This path should emphasize the historic purpose of the river and the overall degradation of the environment caused by the operation of Cracow Soda Works. Places associated with the regeneration of the surrounding nature should be an important part of the path. A small boulevard for the leisure of local residents is to be created in the north-eastern part of the Park.

\section{Jordan Park}

Finally, the land development concept includes the former landfill No. 19, which is located in a depression of the surrounding area. Due to the proximity to the Kurdwanów housing estate and lack of playgrounds the youngest, it was decided to design Jordan Park in this place. The project involves the Park surrounding it with isolating greenery with varying degrees of compactness, preventing cross contamination of the surrounding road system. The park system and equipment shall be adjusted to the needs of the youngest users and include elements of stimulating sensory development of children and people with disabilities.

\section{CONCLUSIONS}

The work on the new landscape development conception for the landfills of former Cracow Soda Works "Solvay" was preceded by historical and current planning documents for the area. The original development plan (from 1994) was taken as the basis for further analysis and studies. A detailed analysis of the current area of the former Cracow Soda Works landfill indicates various forms of civil engineering and public transport as the main directions of development. The performed assessment of physicochemical conditions of the substrate from the landfill sites of former KZS "Solvay" has demonstrated the need of creating parks in this area, as well as recreation and sports. The previously proposed plans and concepts of development trends were partly used in the development of the concept. In addition to these functions, including sacred objects and historical factors related areas is extremely important. Due to the presence of two Christian shrines it is important to incorporate tourism-re- lated functions in the spatial development plans for the southern part of Krakow [Sobczyk, Wawrzyniak 2009; Gliniak 2014; Gliniak, Sobczyk 2014; Poros, Sobczyk 2014].

\section{Acknowledgements}

This Research was financed by the Ministry of Science and Higher Education of the Republic of Poland - DS 3600/WIPiE/2016

\section{REFERENCES}

1. Biuro Rozwoju Krakowa. 1994. Miejscowy plan szczegółowy zagospodarowania przestrzennego terenów Krakowskich Zakładów Sodowych „Solvay" w likwidacji, w rejonie ulic: Zakopiańskiej, Myślenickiej i Podmokłej, skala 1:2000. Kraków.

2. Ciechowski M. 2012. Preferowane kierunki zagospodarowania terenów poprzemysłowych w opinii mieszkańców wybranych miast województwa małopolskiego. Kraków, Instytut Rozwoju Miast, pp. 14.

3. Gliniak M., Sobczyk W. 2014. Koncepcja zagospodarowania terenu poprzemysłowego „Solvay”. Rocznik Naukowy Edukacja-Technika-Informatyka: Problemy edukacji ekologicznej i społecznej, Vol. 5, No. 1, 354-359.

4. Gliniak M. 2014. Kierunki rekultywacji obszarów zdegradowanych działalnością Krakowskich Zakładów Sodowych „Solvay”. Dokonania Młodych Naukowców - wydanie elektroniczne, Vol. 3, No. 2, 266-271.

5. Instytut Rozwoju Miast w Krakowie. 2004. Lokalny program rewitalizacji terenów poprzemysłowych tzw. "Białych Mórz" - założenia programu rewitalizacji. Kraków: Wydawnictwo IRM, pp. 26.

6. Krzak I. 2005. Zagospodarowanie terenów poprzemysłowych Krakowskich Zakładów Sodowych "Solvay" [w:] Szponar, A., HorskaSchwarz, S. (2005) Struktura przestrzenno-funkcjonalna krajobrazu. Problemy Ekologii Krajobrazu, Vol. 17, 283-287.

7. Nagawiecka H., Boroń K., Gałka A., Lipka K. 1980. Biologiczna rekultywacja osadników odpadów posodowych Krakowskich Zakładów Sodowych. Zeszyty Naukowe Akademii Rolniczej w Krakowie, No. 251, 253-259.

8. Okrutniak M. 2010. Rekultywacja Krakowskich Zakładów Sodowych Solvay - sukces czy porażka? Wszechświat, Vol. 111, No. 10-12, 271-276.

9. Poda R. 1999. Solvay wczoraj i dziś. Kraków: Agencja Rozwoju Regionu Krakowskiego S.A., pp. 50. 
10. Poros, M., Sobczyk, W. 2014. Kierunki rekultywacji terenów pogórniczych obszaru chęcińskokieleckiego w kontekście ich wykorzystania w aktywnej edukacji geologicznej. Annual Set The Environment Protection, Vol. 16, 386-403.

11. Pośpiech, N., Skalski, T. 2006. Factors influencing earthworm communities in post-industrial areas of Krakow Soda Works. European Journal of Soil Biology, Vol. 42, 278-283.

12. Sanecki, L. 1994. Charakterystyka istniejących stawów osadowych Krakowskich Zakładów Sodowych i przydatność inwestycyjna terenu osadników. Czasopismo Techniczne - Budownictwo, No. 2, 46-59.

13. Sobczyk, W., Pawul, M. 2010a. Akceptacja społeczna prac rekultywacyjnych na terenach przemysłowych na przykładzie Jastrzębia Zdroju. [W:] Skowronek, J. (red.) (2010). Innowacyjne rozwiązania rewitalizacji terenów zdegra- dowanych. Katowice: Instytut Ekologii Terenów Uprzemysłowionych, 51-58.

14. Sobczyk W., Pawul M. 2010b. Społeczne aspekty rewitalizacji terenów zdegradowanych $\mathrm{w}$ wyniku odkrywkowej eksploatacji siarki w Tarnobrzegu. [W:] Skowronek, J. (red.) 2010. Innowacyjne rozwiązania rewitalizacji terenów zdegradowanych. Katowice: Instytut Ekologii Terenów Uprzemysłowionych, 147-157.

15. Sobczyk W., Wawrzyniak S. 2009. Rewitalizacja obszarów zdegradowanych - budowa zbiornika rekreacyjno-sportowego w Bieruniu Bijasowicach. Przegląd Górniczy, Vol. 65, No. 5-6, 77-81.

16. Uchwała nr LVIII/777/12 Rady Miasta Krakowa z dnia 10 października 2012 r. w sprawie uchwalenia miejscowego planu zagospodarowania przestrzennego obszaru "BIAŁE MORZA". Dziennik Urzędowy Województwa Małopolskiego z dnia 23 października 2012 r. poz. 5215. 